\title{
Awareness level of dentists and dental students about radiation doses of dental imaging methods
}

\author{
G. Özkan1* ${ }^{*}$ R. Sessiz Ak², N. Akkaya3, H. Öztürk4 \\ ${ }^{1}$ Department of Oral and Maxillofacial Radiology, Faculty of Dentistry, Aydın Adnan Menderes University, Aydın, \\ Turkey \\ 2Private practice, Çanakkale, Turkey \\ ${ }^{3}$ Department of Oral and Maxillofacial Radiology, Faculty of Dentistry, Hacettepe University, Ankara, Turkey \\ ${ }^{4}$ Department of Biostatistics, Faculty of Medicine, Aydın Adnan Menderes University, Aydın, Turkey
}

\section{- Original article}

\author{
*Corresponding authors: \\ Dr. Gökhan Özkan, \\ E-mail: \\ asgokhanozkanus@hotmail.com
}

Revised: July 2020

Accepted: July 2020

Int. J. Radiat. Res., July 2021; 19(3): $729-736$

DOI: $10.29252 /$ ijrr.19.2.729

\begin{abstract}
Background: To measure the knowledge levels of dentists and dental students about radiation doses of dental imaging techniques. Materials and Methods: A structured questionnaire containing 13 questions was conducted to 251 participants ( 168 dentists and 83 dental students). The first 6 questions were related to their personal and professional information, and the remaining 7 questions were about the participants' radiation education and knowledge about radiation doses. Chi-square test was used to determine the relationship between categorical variables, and $P<0.05$ was considered statistically significant. Results: The data from 144 (57.4\%) women and 107 (42.6\%) men were obtained. Gender was not effective on knowledge about radiation doses during dental imaging $(p=0.222)$. The knowledge of dentists working at the university was statistically higher than those working in the state hospital or private dental offices ( $p<0.001$ ). Of the participants, $43.4 \%$ ( $n=109$ ) stated that the craniofacial mode of cone beam computerized tomography radiates less radiation than the actual dose range, while $32.7 \%$ (n = 82) said they had no idea. Conclusion: Most of the dentists and dental students underestimated the actual radiation doses of dental imaging techniques. The dental curriculum should be revised to emphasize radiation protection during imaging. In addition, compulsory vocational postgraduate courses should be organized.
\end{abstract}

Keywords: Awareness, dental imaging, radiation dose, questionnaire.

\section{INTRODUCTION}

Radiation may cause adverse biological effects for living organisms, and medical applications constitute the majority of the artificial radiation sources that contain ionizing radiation $(1,2)$. Ionizing radiation can induce mutations in DNA, thus increasing the risk of cancer $(3,4)$. Such harmful biological effects are not only related to the amount of radiation and duration of exposure but also depend on patient-related factors such as age, gender and size, technical factors, and selected devices (5). The United Nations Scientific Committee on the Atomic Radiation (UNSCEAR) stated that 360 out of 1000 people are exposed to radiation for medical and dental purposes (6). The literature in the fields contains studies about the knowledge of medical doctors, medical students, and radiology staff on the dose values of medical imaging techniques (1,7-11). Medical imaging researches have tried to highlight the potential risks and awareness of physicians to the doses of radiation exposure during the radiological procedures. Dental imaging devices have different imaging technologies and some techniques such as cone beam computed tomography (CBCT) contain relatively higher ionizing radiation than the other devices $(4,12,13)$. Additional units were presented in dental markets with various stages of development after the first approval of CBCT by the FDA for 
dental use in 2001 (14).

Due to the rapid development of contemporary and traditional dental imaging methods, the knowledge level of dentists requesting these imaging modalities is crucial. Although it is difficult to prove, it is believed that approximately 100-150 people die from cancer due to medical radiation exposure $(7,15)$. Radiation doses of dental imaging techniques are relatively low, but these techniques constitute one-third of all radiological examinations in Europe (16). Clinicians should take into account the cumulative effects of repeated exposure, which can increase the risk of parotid gland tumor, thyroid tumor, and intracranial meningioma (17-19). In addition to initial diagnostic radiographs, dentists may require supplementary intraoral and extraoral radiological imaging to be performed throughout the dental treatment due to orthodontic, endodontic, and surgical reasons (12).

Ludlow et al. (20) reported that dental radiographic procedures are $32 \%$ to $422 \%$ riskier than previously considered. The aim of the present study was to measure the awareness level of dentists about radiation exposure doses of dental imaging techniques and encourage clinicians to redesign their diagnostic approaches and treatment plans to protect patients from unnecessary ionizing radiation. There are few studies in the literature on this subject; thus, the information presented here contributes to the literature on the radiation doses for dental imaging techniques and the knowledge level of clinicians.

\section{MATERIALS AND METHODS}

This descriptive and cross-sectional study was approved by the Ethics Committee of the Aydın Adnan Menderes University (Protocol no. ADUDHF2018/024) and was implemented between March 2018 and October 2018. A pilot survey was conducted for 20 students to validate the questionnaire. The questionnaires were applied to dental students and dentists (except dental radiologists) after the questionnaires were determined to be clear and valid. A structured questionnaire containing 13 questions was conducted to 251 volunteers living in the center of the city of Aydın. The questionnaires were delivered to the participants by the researchers themselves, and they were received after the surveys were completed under supervision. The first 6 questions addressed personal and professional information, including their age, gender, institution, area of expertise, and duration of professional practice, while the remaining 7 questions were about the participants' radiation education, attitudes regarding informing patients about radiation doses, and the level of their knowledge about radiation doses during dental imaging procedures. The designed questionnaire was based on the literature reviewed $(1,7,9,11)$. The answers about doses of ionizing radiation during dental imaging procedures were evaluated according to the dose ranges accepted by the European Commission on Radiation Protection (21). These dose ranges were: 280-1410 $\mu \mathrm{Sv}$ for maxillo-mandibular multislice computed tomography (MSCT); 30-1073 $\mu \mathrm{Sv}$ for craniofacial CBCT; 11-674 $\mu \mathrm{Sv}$ for dentoalveolar CBCT; $2.7-24.3 \mu \mathrm{Sv}$ for a panoramic radiograph; $<6 \mu \mathrm{Sv}$ for a cephalometric radiograph; and $<1.5$ $\mu \mathrm{Sv}$ for an intraoral radiograph using a photostimulable phosphor plate or F-speed film with rectangular collimation. For the CBCT device, large field of view (FOV) was referred to as "craniofacial" and small and medium FOVs as "dentoalveolar".

\section{Statistics}

Data were analyzed using the statistical software package SPSS v22.0 (Armonk, NY: IBM Corp). To determine the relationship between categorical variables, Pearson and Yates' chi-square tests were performed. The Mann-Whitney U test and Kruskal-Wallis H test were used for the comparison of two and more than two independent groups, respectively. Descriptive statistics were given in frequency and percentage form for categorical variables, and a median (25-75 percentiles) was given for numerical variables. $\mathrm{P}<0.05$ was considered 
statistically significant.

\section{RESULTS}

A total of 251 participants participated in the study. Mean age of the participants was $31.53 \pm$ 10.74 years. Of these, $144(57.4 \%)$ were female and 107 (42.6\%) were male (ranging between 20 to 66 years). Of the participants, $168(67.9 \%)$ were dentists, and 83 (33.1\%) were dental students (19 fourth year and 64 third year). All the participating students had previously attended the lessons on radiation protection. Of the 168 dentists, 37 were employed in the state hospital, 64 in private dental offices, and 67 in the university. The distribution of the sociodemographic features of the study group is represented in table 1 . Of the participants, 226 $(90 \%)$ stated that they had radiation safety education.

Table 1. Distribution of sociodemographic features of the study group.

\begin{tabular}{|c|c|c|}
\hline & $\mathbf{n}$ & \% \\
\hline Gender & & \\
\hline Female & 144 & 57.4 \\
\hline Male & 107 & 42.6 \\
\hline Institution & & \\
\hline University & 150 & 59.8 \\
\hline State Hospital & 37 & 14.7 \\
\hline Private office & 64 & 25.5 \\
\hline Years of service & & \\
\hline Student & 83 & 33.1 \\
\hline 0-1 year & 25 & 10.0 \\
\hline 1-5 years & 40 & 15.9 \\
\hline 5-10 years & 23 & 9.2 \\
\hline 10+ years & 80 & 31.8 \\
\hline Specialty & & \\
\hline Student & 83 & 33.1 \\
\hline General dentist & 83 & 33.1 \\
\hline Pedodontist & 13 & 5.2 \\
\hline Orthodontist & 12 & 4.7 \\
\hline Periodontologist & 23 & 9.1 \\
\hline Endodontist & 9 & 3.6 \\
\hline Prosthodontist & 9 & 3.6 \\
\hline Total & 13 & 2.4 \\
\hline & 251 & 100.0 \\
\hline
\end{tabular}

Int. J. Radiat. Res., Vol. 19 No. 3, July 2021
However, only 79 (31.5\%) of the participants stated that they provided information to their patients about the radiation dose. The responses to the question, "What is your priority when you offer a radiograph?" were as follows: 33.1\% (83) pay attention to the radiological algorithm, $22.3 \%$ (56) to fast imaging, $20.3 \%$ (51) to the radiation dose, and $18.3 \%$ (46) to easy accessibility. The average percentage of correct responses given by 251 individuals for all techniques was $36.8 \%$. This rate was $35.5 \%$ for men and $37.8 \%$ for women, with no statistical differences between genders on knowledge of radiation dose ranges during dental imaging $(p=0.222)$. Association of the participants' gender with imaging techniques is represented in table 2 . The knowledge about radiation dose ranges during dental imaging was higher in dentists working at the university than in those working at the state hospital and private dental offices $(p<0.001)$. Association of the participants' institution with their awareness about imaging techniques is represented in table 3. The knowledge of specialists and students was statistically higher than that of general dentists $(p<0.05)$, and there was no significant difference between students and specialists $(p=0.191)$.

When the duration of professional practice was considered, the knowledge of the $<1$ year, 1 -5 years and $6-10$ years groups was higher than that of the dentists working $>10$ years, and this difference was significant $(\mathrm{p}<0.001)$. Association of the participants' years of service with imaging techniques is represented in table 4. It was revealed that $35.1 \%(n=88)$ of the participants do not have knowledge of ultrasonography (USG), and $43.4 \%(n=109)$ did not know that magnetic resonance imaging (MRI) does not utilize ionizing radiation. While $49.8 \%(n=125)$ of the participants stated that MSCT emits less radiation, $32.7 \%(\mathrm{n}=82)$ reported that they had no idea. Similarly, $43.4 \%$ of the participants $(n=109)$ declared that craniofacial CBCT emits less radiation, while $32.7 \%(n=82)$ had no idea.

Distribution of the responses to the questions about the radiation exposure ranges for dental imaging techniques that use ionizing radiation is shown in table 5 . As observed, $32.7 \%$ of the participants had no idea about the radiation 
exposure dose ranges with CBCT-dentoalveolar, CBCT-craniofacial and MSCT. Almost half of the participants declared lower than actual doses for MSCT. Similarly, $45.4 \%$ stated less than actual doses with panoramic, $43.4 \%$ with
CBCT-craniofacial and $37.5 \%$ with CBCTdentoalveolar imaging methods. Even though $63.8 \%$ accurately reported the radiation dose range of intraoral radiographs, $22.3 \%$ had no idea.

Table 2. Association of the participants' gender and imaging techniques.

\begin{tabular}{|c|c|c|c|c|}
\hline \multirow{2}{*}{ Imaging Technique } & \multicolumn{2}{|c|}{ Gender } & \multirow{2}{*}{ Chi-square } & \multirow{2}{*}{$P$ value } \\
\hline & Female $\mathrm{n}(\%)$ & Male n (\%) & & \\
\hline $\begin{array}{c}\text { Intraoral Radiograph } \\
\text { Right } \\
\text { Wrong }\end{array}$ & $\begin{array}{l}95(66.0) \\
49(34.0)\end{array}$ & $\begin{array}{l}65(60.7) \\
42(39.3)\end{array}$ & 0.725 & 0.394 \\
\hline $\begin{array}{l}\text { USG } \\
\text { Right } \\
\text { Wrong }\end{array}$ & $\begin{array}{c}102(70.8) \\
42(29.2)\end{array}$ & $\begin{array}{l}61(57.0) \\
46(43.0)\end{array}$ & 5.152 & 0.023 \\
\hline $\begin{array}{l}\text { MSCT } \\
\text { Right } \\
\text { Wrong }\end{array}$ & $\begin{array}{c}24(16.7) \\
120(83.3)\end{array}$ & $\begin{array}{l}20(18.7) \\
87(81.3)\end{array}$ & 0.062 & 0.803 \\
\hline $\begin{array}{c}\text { Cephalometric Radiograph } \\
\text { Right } \\
\text { Wrong }\end{array}$ & $\begin{array}{c}44(30.6) \\
100(69.4)\end{array}$ & $\begin{array}{l}33(30.8) \\
74(69.2)\end{array}$ & 0.002 & 0.961 \\
\hline $\begin{array}{c}\text { CBCT-Dento-alveolar } \\
\text { Right } \\
\text { Wrong } \\
\end{array}$ & $\begin{array}{c}34(23.6) \\
110(76.4)\end{array}$ & $\begin{array}{l}26(24.3) \\
81(75.7)\end{array}$ & 0.016 & 0.899 \\
\hline $\begin{array}{c}\text { CBCT-Craniofacial } \\
\text { Right } \\
\text { Wrong } \\
\end{array}$ & $\begin{array}{c}21(14.6) \\
123(85.4)\end{array}$ & $\begin{array}{l}20(18.7) \\
87(81.3)\end{array}$ & 0.487 & 0.485 \\
\hline $\begin{array}{l}\text { MRI } \\
\text { Right } \\
\text { Wrong }\end{array}$ & $\begin{array}{l}87(60.4) \\
57(39.6)\end{array}$ & $\begin{array}{l}55(51.4) \\
52(48.6)\end{array}$ & 2.031 & 0.154 \\
\hline $\begin{array}{c}\text { Panoramic Radiograph } \\
\text { Right } \\
\text { Wrong }\end{array}$ & $\begin{array}{c}28(19.4) \\
116(80.6)\end{array}$ & $\begin{array}{l}24(22.4) \\
83(77.6)\end{array}$ & 0.176 & 0.675 \\
\hline
\end{tabular}

USG: ultrasonography, MSCT: multislice computed tomography, CBCT: cone beam computed tomography, MRI: magnetic resonance imaging 
Table 3. Association of the Participants' Institution and Imaging Techniques.

\begin{tabular}{|c|c|c|c|c|c|c|}
\hline \multirow{2}{*}{ Imaging Technique } & \multicolumn{4}{|c|}{ Institution } & \multirow[b]{2}{*}{ Chi-square } & \multirow[b]{2}{*}{ p } \\
\hline & Student n(\%) & University $n(\%)$ & State hospital n(\%) & Private office $n(\%)$ & & \\
\hline $\begin{array}{c}\text { Intraoral Radiograph } \\
\text { Right } \\
\text { Wrong } \\
\end{array}$ & $\begin{array}{l}50(60.2) \\
33(39.8)\end{array}$ & $\begin{array}{l}49(73.1) \\
18(26.9)\end{array}$ & $\begin{array}{l}22(59.5) \\
15(40.5)\end{array}$ & $\begin{array}{l}39(60.9) \\
25(39.1)\end{array}$ & 3.509 & 0.320 \\
\hline $\begin{array}{l}\text { USG } \\
\text { Right } \\
\text { Wrong }\end{array}$ & $\begin{array}{l}59(71.1) \\
24(28.9)\end{array}$ & $\begin{array}{c}58(86.6) \\
9(13.4)\end{array}$ & $\begin{array}{l}13(35.1) \\
24(64.9)\end{array}$ & $\begin{array}{l}33(51.6) \\
31(48.4)\end{array}$ & 34.607 & 0.000 \\
\hline $\begin{array}{c}\text { MSCT } \\
\text { Right } \\
\text { Wrong }\end{array}$ & $\begin{array}{l}13(15.7) \\
70(84.3)\end{array}$ & $\begin{array}{l}19(28.4) \\
48(71.6)\end{array}$ & $\begin{array}{c}2(5.4) \\
35(94.6)\end{array}$ & $\begin{array}{l}10(15.6) \\
54(84.4)\end{array}$ & 9.557 & 0.023 \\
\hline $\begin{array}{c}\text { Cephalometric Radiograph } \\
\text { Right } \\
\text { Wrong } \\
\end{array}$ & $\begin{array}{l}29(34.9) \\
54(65.1)\end{array}$ & $\begin{array}{l}17(25.4) \\
50(74.6)\end{array}$ & $\begin{array}{c}6(16.2) \\
31(83.8)\end{array}$ & $\begin{array}{l}25(39.1) \\
39(60.9)\end{array}$ & 7.350 & 0.062 \\
\hline $\begin{array}{c}\text { CBCT-Dento-alveolar } \\
\text { Right } \\
\text { Wrong } \\
\end{array}$ & $\begin{array}{l}18(21.7) \\
65(78.3)\end{array}$ & $\begin{array}{l}19(28.4) \\
48(71.6) \\
\end{array}$ & $\begin{array}{c}4(10.8) \\
33(89.2)\end{array}$ & $\begin{array}{l}19(29.7) \\
45(70.3) \\
\end{array}$ & 5.619 & 0.132 \\
\hline $\begin{array}{l}\text { CBCT-Craniofacial } \\
\text { Right } \\
\text { Wrong }\end{array}$ & $\begin{array}{l}16(19.3) \\
67(80.7)\end{array}$ & $\begin{array}{c}8(11.9) \\
59(88.1)\end{array}$ & $\begin{array}{c}4(10.8) \\
33(89.2)\end{array}$ & $\begin{array}{l}13(20.3) \\
51(79.7)\end{array}$ & 3.040 & 0.386 \\
\hline $\begin{array}{c}\text { MRI } \\
\text { Right } \\
\text { Wrong }\end{array}$ & $\begin{array}{l}46(55.4) \\
37(44.6)\end{array}$ & $\begin{array}{l}55(82.1) \\
12(17.9)\end{array}$ & $\begin{array}{l}13(35.1) \\
24(64.9)\end{array}$ & $\begin{array}{l}28(43.8) \\
36(56.3)\end{array}$ & 29.006 & 0.000 \\
\hline $\begin{array}{c}\text { Panoramic Radiograph } \\
\text { Right } \\
\text { Wrong } \\
\end{array}$ & $\begin{array}{l}15(18.1) \\
68(81.9)\end{array}$ & $\begin{array}{l}22(32.8) \\
45(67.2)\end{array}$ & $\begin{array}{c}4(10.8) \\
33(89.2)\end{array}$ & $\begin{array}{l}11(17.2) \\
53(82.8)\end{array}$ & 9.040 & 0.029 \\
\hline
\end{tabular}

USG: ultrasonography, MSCT: multislice computed tomography, CBCT: cone beam computed tomography, MRI: magnetic resonance imaging.

Table 4. Association of the participants' years of service and imaging techniques.

\begin{tabular}{|c|c|c|c|c|c|c|}
\hline \multirow{2}{*}{ Imaging Technique } & \multicolumn{4}{|c|}{ Years of service } & \multirow[b]{2}{*}{ Chi-square } & \multirow[b]{2}{*}{$\mathbf{p}$} \\
\hline & $0-1$ year $n(\%)$ & $1-5$ years $n(\%)$ & $6-10$ years $n(\%)$ & $10+$ years $n(\%)$ & & \\
\hline $\begin{array}{c}\text { Intraoral Radiograph } \\
\text { Right } \\
\text { Wrong } \\
\end{array}$ & $\begin{array}{c}20(80.0) \\
5(20.0)\end{array}$ & $\begin{array}{c}31(77.5) \\
9(22.5)\end{array}$ & $\begin{array}{l}13(56.5) \\
10(43.5)\end{array}$ & $\begin{array}{l}46(57.5) \\
34(42.5) \\
\end{array}$ & 7.959 & 0.047 \\
\hline $\begin{array}{c}\text { USG } \\
\text { Right } \\
\text { Wrong }\end{array}$ & $\begin{array}{c}24(96.0) \\
1(4.0)\end{array}$ & $\begin{array}{c}32(80.0) \\
8(20.0)\end{array}$ & $\begin{array}{c}16(69.6) \\
7(30.4)\end{array}$ & $\begin{array}{l}32(40.0) \\
48(60.0)\end{array}$ & 34.727 & $<0.001$ \\
\hline $\begin{array}{l}\text { MSCT } \\
\text { Right } \\
\text { Wrong }\end{array}$ & $\begin{array}{c}6(24.0) \\
19(76.0)\end{array}$ & $\begin{array}{l}13(32.5) \\
27(67.5)\end{array}$ & $\begin{array}{c}2(8.7) \\
21(91.3)\end{array}$ & $\begin{array}{l}10(12.5) \\
70(87.5)\end{array}$ & 8.924 & $0.012^{*}$ \\
\hline $\begin{array}{c}\text { Cephalometric Radiograph } \\
\text { Right } \\
\text { Wrong }\end{array}$ & $\begin{array}{c}4(16.0) \\
21(84.0)\end{array}$ & $\begin{array}{l}13(32.5) \\
27(67.5)\end{array}$ & $\begin{array}{c}8(34.8) \\
15(65.2)\end{array}$ & $\begin{array}{l}23(28.8) \\
57(71.2)\end{array}$ & 2.675 & 0.445 \\
\hline $\begin{array}{c}\text { CBCT-Dento-alveolar } \\
\text { Right } \\
\text { Wrong }\end{array}$ & $\begin{array}{c}8(32.0) \\
17(68.0)\end{array}$ & $\begin{array}{l}14(35.0) \\
26(65.0)\end{array}$ & $\begin{array}{c}7(30.4) \\
16(69.6)\end{array}$ & $\begin{array}{l}13(16.2) \\
67(83.8)\end{array}$ & 6.416 & 0.093 \\
\hline $\begin{array}{c}\text { CBCT-Craniofacial } \\
\text { Right } \\
\text { Wrong } \\
\end{array}$ & $\begin{array}{c}6(24.0) \\
19(76.0) \\
\end{array}$ & $\begin{array}{c}7(17.5) \\
33(82.5)\end{array}$ & $\begin{array}{c}3(13.0) \\
20(87.0) \\
\end{array}$ & $\begin{array}{c}9(11.2) \\
71(88.8)\end{array}$ & 2.707 & $0.258^{*}$ \\
\hline $\begin{array}{c}\text { MRI } \\
\text { Right } \\
\text { Wrong }\end{array}$ & $\begin{array}{c}22(88.0) \\
3(12.0)\end{array}$ & $\begin{array}{l}28(70.0) \\
12(30.0)\end{array}$ & $\begin{array}{c}14(60.9) \\
9(39.1)\end{array}$ & $\begin{array}{l}32(40.0) \\
48(60.0)\end{array}$ & 22.150 & $<0.00$ \\
\hline $\begin{array}{c}\text { Panoramic Radiograph } \\
\text { Right } \\
\text { Wrong } \\
\end{array}$ & $\begin{array}{c}7(28.0) \\
18(72.0)\end{array}$ & $\begin{array}{l}12(30.0) \\
28(70.0)\end{array}$ & $\begin{array}{c}5(21.7) \\
18(78.3)\end{array}$ & $\begin{array}{l}13(16.2) \\
67(83.8)\end{array}$ & 3.556 & 0.314 \\
\hline
\end{tabular}

*Since the ratio of expected count which are less than 5 was larger than $20 \%$ the categories " $5-10$ years" and "10+ years" were integrated. USG: ultrasonography, MSCT: multislice computed tomography, СВСТ: cone beam computed tomography, MRI: magnetic resonance imaging 


\section{Özkan et al. / Radiation doses of dental imaging methods}

Table 5. Distribution of responses to questions about radiation exposure dose range of dental imaging techniques that use ionizing radiation.

\begin{tabular}{|c|c|c|c|c|c|c|c|c|}
\hline & \multicolumn{2}{|c|}{ No idea } & \multicolumn{2}{c|}{$\begin{array}{c}\text { Less than the } \\
\text { actual dose range }\end{array}$} & \multicolumn{2}{c|}{$\begin{array}{c}\text { In the dose } \\
\text { range }\end{array}$} & \multicolumn{2}{c|}{$\begin{array}{c}\text { More than the } \\
\text { actual dose range }\end{array}$} \\
\hline Imaging Technique & $\mathbf{n}$ & $\mathbf{\%}$ & $\mathbf{n}$ & $\mathbf{\%}$ & $\mathbf{n}$ & $\mathbf{\%}$ & $\mathbf{n}$ & $\mathbf{\%}$ \\
\hline Intraoral Radiograph & 56 & 22.3 & 0 & 0.0 & 160 & 63.8 & 35 & 13.9 \\
\hline MSCT & 82 & 32.7 & 125 & 49.8 & 44 & 17.5 & 0 & 0.0 \\
\hline Cephalometric Radiograph & 77 & 30.7 & 15 & 6.0 & 77 & 30.7 & 82 & 32.7 \\
\hline CBCT-Dento-alveolar & 82 & 32.7 & 94 & 37.5 & 60 & 23.9 & 15 & 6.0 \\
\hline CBCT-Craniofacial & 82 & 32.7 & 109 & 43.4 & 41 & 16.3 & 19 & 7.6 \\
\hline Panoramic Radiograph & 57 & 22.7 & 114 & 45.4 & 52 & 20.7 & 28 & 11.2 \\
\hline
\end{tabular}

\section{DISCUSSION}

Radiation dose is mostly expressed as effective dose (Sievert, Sv) and this was preferred in the study as it considers the radiation dose and the type, quantity, and sensitivity of the irradiated tissue ${ }^{(5,21)}$. It can be calculated by taking the equivalent doses to the exposed tissues in the body and multiplying them by the relevant tissue weighting factor. Then, the weighted doses are summed to obtain the effective dose, which is used to determine the risk of cancer in a person $(1,5,22)$. Since the measurement of effective dose is impossible in humans, it can be determined in laboratory conditions or via computer modeling to estimate the radiation risk $(4,23)$. In the literature, many studies estimated and compared the radiation doses of MSCT, CBCT, intraoral, and extraoral dental imaging techniques using anthropomorphic phantoms with dosimeters ${ }^{(12,}$ 19, 22, 24-26).

Nowadays, CBCT is the most preferred technique in dentistry because of minimal magnification, superimposition, and distortion $(12,13)$. However, the radiation dose of CBCT is usually higher than that of conventional dental radiography techniques but lower than that of MSCT scans of the maxillary-mandibular region $(19,20,25,27)$. The actual radiation dose of CBCT is not fully known by dentists because of the variations in exposure parameters, receptor technology, human factors and selected FOV (5). Also, CBCT is frequently offered after conventional dental imaging techniques (intraoral, panoramic, and cephalometric radiographs) which lead to increased cumulative effects of radiation (12,19). Risk of death between 1 in 10,000 and 1 in 100,000 is considered an acceptable risk by the National Council on Radiation Protection and Measurements (NCRP). It is thought that the risk of cancer with CBCT is slightly greater than 1 in $1,000,000$ (28), which is three times higher in children; and a large FOV and high-resolution CT scans can cause cancer to 1 in 10,000 children (5). In one of the most recent studies, Ludlow et al. (26) suggested that CBCT doses could be further reduced by $36-51 \%$ with Lite (lower, kVp-reduced dose) exposure protocols, particularly in children and in cases where increased image noise will not interfere with the diagnostic task. In addition, Widmann and Al-Ekrish (29) suggested that application of ultralow dose MSCT with image reconstruction technology in dental implantology may have potential for large dose reductions.

Most of the studies that have evaluated the knowledge level of medical doctors and radiology staff with respect to radiation protection and radiation doses of medical imaging methods indicate that doctors, medical students, and staff have insufficient information of the same $(1,7,10,11)$. Similarly, the dentists and dental students surveyed in the present study also exhibited insufficient knowledge. In addition, most of the dentists failed to provide their patients with information about the radiation doses of dental imaging methods, which may be a result of their insufficient knowledge levels. Even though the participants have previously undergone radiation protection education, $20.3 \%$ and $12.4 \%$ of the participants, respectively, supposed that MRI and USG are the techniques that use ionizing radiation. In addition, 58 (23.1\%) for MRI and 57 (22.7\%) for 
USG had no idea whether these devices utilized ionizing radiation. This lack of knowledge may cause dentists to not prefer these techniques as additional dental imaging methods. General dentists have shown a lower level of knowledge, and this may be a consequence of relatively lower number of radiological examination requests during their clinical practice. Also, the low knowledge levels of dentists with over ten years of work experience can be attributed to their reluctance to participate in voluntary vocational training. The results of this study also revealed that the knowledge level of dentists may vary according to occupational differences such as institution, service years, and whether or not they were academicians. The relationships among specialist dentists could not be evaluated statistically because of large differences between the number of participants from different departments. Conducting a similar study with dentists from across the country may be more appropriate to determine differences in knowledge levels between specialist dentists according to their departments. Since the participants' ages cannot reflect the exact knowledge of the dentists in dental radiology, this feature was not evaluated.

This study provides important information about dentists' knowledge about the radiation doses of dental imaging techniques, i.e., most of the dentists and dental students surveyed underestimated the actual radiation doses during dental imaging procedures. This lack of knowledge may lead to dentists seeking radiological imaging more than necessary. Since stochastic radiation effects can cause cancer or hereditary problems, any dose of radiation for dental imaging should be considered a potential health risk (24,27). Therefore, it is crucial for dentists and radiology staff to ensure the minimal dose of radiation for patients in accordance with the "as low as diagnostically acceptable" (ALADA) principle (30).

\section{CONCLUSION}

Dentists should request radiographs only if they will provide positive benefits for diagnosis and treatment planning, and they should consider the radiograph selection criteria to avoid unnecessary ionizing radiation. Thus, dental curriculum should be revised to devote more time to radiation safety issues to ensure minimum radiation exposure of patients and radiology personnel. Moreover, compulsory postgraduate vocational courses should be organized to update the knowledge about radiation doses.

\section{Conflicts of interest: Declared none.}

\section{REFERENCES}

1. Divrik Gökçe S, Gökçe E, Coşkun M (2012) Radiology residents' awareness about ionizing radiation doses in imaging studies and their cancer risk during radiological examinations. Korean J Radiol, 13: 202-209.

2. Sont WN, Zielinski JM, Ashmore JP, Jiang H, Krewski D, Fair $\mathrm{ME}$, et al. (2001) First analysis of cancer incidence and occupational radiation exposure based on the National Dose Registry of Canada. Am J Epidemiol, 153: 309-318.

3. Brenner DJ, Doll R, Goodhead DT, Hall EJ, Land CE, Little JB, et al. (2003) Cancer risks attributable to low doses of ionizing radiation: assessing what we really know. Proc Natl Acad Sci, 100:13761-13766.

4. Lorenzoni DC, Bolognese AM, Garib DG, Guedes FR, Sant'anna EF (2012) Cone-beam computed tomography and radiographs in dentistry: aspects related to radiation dose. Int J Dent, 813768.

5. Aanenson JW, Till JE, Grogan HA (2018) Understanding and communicating radiation dose and risk from cone beam computed tomography in dentistry. J Prosthet Dent, 120: $353-360$.

6. United Nations Scientific Committee on the Atomic Radiation (2010) UNSCEAR 2008 Report Vol. I: sources and effects of ionizing radiation.

7. Arslanoğlu A, Bilgin S, Kubal Z, Ceyhan MN, Ilhan MN, Maral I (2007) Doctors' and intern doctors' knowledge about patients' ionizing radiation exposure doses during common radiological examinations. Diagn Interv Radiol, 13: 53 -55 .

8. Faggioni L, Paolicchi F, Bastiani L, Guido D, Caramella D (2017) Awareness of radiation protection and dose levels of imaging procedures among medical students, radiography students, and radiology residents at an academic hospital: Results of a comprehensive survey. Eur J Radiol, 86: 135-142.

9. Gümüş C, Cankorkmaz L, Erkoç MF, Öztoprak B, Atalar M, Köylüoğlu G (2008) Turkish pediatric surgeons knowledge on the radiation exposure of patients during diagnostic 


\section{Özkan et al. / Radiation doses of dental imaging methods}

imaging. Turkiye Klinikleri J Med Sci, 28: 623-627.

10. Shiralkar S, Rennie A, Snow M, Galland RB, Lewis $M H$, Gower-Thomas K (2003) Doctors' knowledge of radiation exposure: questionnaire study. BMJ, 327: 371-372.

11. Yurt A, Cavuşoğlu B, Günay T (2014) Evaluation of awareness on radiation protection and knowledge about radiological examinations in healthcare professionals who useionized radiation at work. Mol Imaging Radionucl Ther, 23: 48-53.

12. Wrzesień M and Olszewski J (2017) Absorbed doses for patients undergoing panoramic radiography, cephalometric radiography and СВCT. Int J Occup Med Environ Health, 30: 705-713.

13. Yeh JK, Chen $\mathrm{CH}$ (2018) Estimated radiation risk of cancer from dental cone-beam computed tomography imaging in orthodontics patients. BMC Oral Health, 18: 131.

14. Scarfe WC, Levin MD, Gane D, Farman AG (2009) Use of cone beam computed tomography in endodontics. Int $J$ Dent, 634567.

15. Jacob K, Vivian G, Steel (2004) JR X-ray dose training: are we exposed to enough? Clin Radiol, 59: 928-934.

16. European Commission, Radiation Protection 180, Medical Radiation Exposure for the European Population, Office for Official Publications of the European Communities. Luxembourg, 2014. Availablefrom: https://ec.europa.eu/ energy/en/radiation-protection-publications.

17. Abt E (2012) Can dental x-rays increase the risk of meningioma? Evid Based Dent, 13: 37-38.

18. Memon A, Godward S, Williams D, Siddique I, Al-Saleh K (2010) Dental X-rays and the risk of thyroid cancer: a casecontrol study. Acta Oncol 49, 447-453.

19. Qiang W, Qiang F, Lin L (2019) Estimation of effective dose of dental X-ray devices. Radiat Prot Dosimetry, 183: 417421.

20. Ludlow JB, Davies-Ludlow LE, White SC (2008) Patient risk related to common dental radiographic examinations: the impact of 2007 International Commission on Radiological
Protection recommendations regarding dose calculation. $J$ Am Dent Assoc, 139: 1237-1243.

21. European Commission, Radiation protection 172, Cone beam CT for dental and maxillofacial radiology, evidencebased guidelines. Luxembourg, 2012. Available from: https://ec.europa.eu/energy/sites/ener/files/ documents/172.pdf

22. Ludlow JB, Davies-Ludlow LE, Brooks SL (2003) Dosimetry of two extraoral direct digital imaging devices: NewTom cone beam CT and Orthophos Plus DS panoramic unit. Dentomaxillofac Radiol, 32: 229-234.

23. European Commission, Radiation protection 136, European guidelines on radiation protection in dental radiology, the safe use of radiographs in dental practice. Luxembourg, 2004. Available from: https://ec.europa.eu/energy/ sites/ener/files/documents/136.pdf

24. Gijbels F, Sanderink G, Wyatt J, Van Dam J, Nowak B, Jacobs $R$ (2004) Radiation doses of indirect and direct digital cephalometric radiography. Br Dent J, 197: 149152.

25. Ludlow JB and Ivanovic M (2008) Comparative dosimetry of dental CBCT devices and 64-slice CT for oral and maxillofacial radiology. Oral Surg Oral Med Oral Pathol Oral Radiol Endo, 106: 106-114.

26. Ludlow JB, Johnson BK, Ivanovic M (2018) Estimation of effective doses from MDCT and $C B C T$ imaging of extremities. J Radiol Prot, 38: 1371-1383.

27. Okano T and Sur J (2010) Radiation dose and protection in dentistry. Japanese Dental Science Review, 46: 112-121.

28. National Council on Radiation Protection and Measurements (2018) NCRP report 177: radiation protection in dentistry and oral and maxillofacial imaging. Bethedsa.

29. Widmann G and Al-Ekrish AA (2018) Ultralow Dose MSCT Imaging in Dental Implantology. Open Dent J, 12: 87-93.

30. Jaju PP and Jaju SP (2015) Cone-beam computed tomography: Time to move from ALARA to ALADA. Imaging Sci Dent, 45: 263-265. 